\title{
Effectiveness Legal Formal of Education Culture Heritage at Van Den Bosch Fort in Indonesian
}

\author{
Karyoto $^{1}$, N Chasanah ${ }^{2}$, D Sisbiantoro ${ }^{3}$, W H Setyawan ${ }^{4}$, M Huda $^{5}$ \\ 1,2,3,4 Universitas Islam Kadiri, Kediri, ${ }^{5}$ Universitas Sekolah Tinggi Ilmu Hukum IBLAM \\ Jakarta \\ 1yotoahmad@gmail.com, ${ }^{2}$ nurchasanah@uniska-kediri.ac.id, ${ }^{3}$ sisbiantoro@uniska-kediri.ac.id, \\ ㄴwawansetyawan@uniska-kediri.ac.id, ${ }^{5}$ misbahhuda464@gmail.com,
}

\begin{abstract}
This study aimed to know the effectiveness of the location of the land and building of Van Den Bosch fort Ngawi to be education culture heritage. Since Indonesian Independence on August 17, 1945, changed the ownership status of the Colonial Dutch Nation, to be an asset of the Republic of Indonesia, formerly used for the Ngawi Armed Battalion, now the location is Tourism for public. The results of this study showed that the land in the Government of Indonesia's Ngawi Regency area of: 158,798 M2 which contained relics of the Dutch Knil Army, when the Dutch were in Indonesia, the name of the Van Den Bosch fort Ngawi. The Van Den Bosch's building ownership is an asset of the Republic of Indonesia, based on Perpu No. 23 of 1959 concerning the Revocation of Law No. 74 in 1957. The building is not effective became the Education Cultural Heritage..
\end{abstract}

Keywords: effectiveness, Van Den Bosch Fort, Education Culture Heritage

\section{INTRODUCTION}

The tourism sector is a potential sector to be developed as a source of regional income. Efforts to enlarge the region's original income, the development program and utilization of resources and regional tourism potential are expected to contribute to economic development. Tourism is seen as a multidimensional activity in a series of development processes. The development of the tourism sector concerns social, economic and political aspects. Other attractions in Ngawi district with potential bridal falls in Ngrambe area, Srambang Waterfall in Jogorogo district, Pendem Fort in Ngawi City, Trinil Museum in Kedah district, Srigati Tour in Paron district, Soerjo Monument in Kedar district, Tawun Recreational Park in Kasreman district, Pond Reservoir in Bringin district, Sangiran reservoir in Bringin district, Jamus tea plantation in Sine district and more. One of interested in destination is van den bosch fort ngawi. It is known to the public as a military place and should not be visited by the general public, so since 2013 the Pendem Fort was opened to the public by the Regional Government of Ngawi Regency, so starting that year the Cultural and Youth Tourism Office promoted it as one of the historical tourism objects in the district Ngawi.

Land is a major supporting factor in the management of national and state life, for the welfare and survival of its people. During the Diponegoro war in 1825-1830 to fight the Dutch colonial in Ngawi. It led by Adipati Judo Diningrat and Raden Tumenggung Suro Dirdjo with Wirotani. They were Prince Diponegoro's army, for the Madiun area against the Dutch colonists. Ngawi and Madiun are strategic places in East Java as the Trade and Shipping Center through 
the Solo River, which links Surabaya-Solo in the area of Java. Then Ngawi by the Dutch Knil Army was made the Dutch War Defense Center in the Madiun area, during the Diponegoro War.

In 1825 Ngawi was successfully conquered by the Dutch Knil Army, so to maintain control of the Madiun-Ngawi region, the Dutch Knil Army, built the Pendenm Fortress or called the Van Den Bosch Fort Ngawi. Dutch Knil Army, built Benteng Pendem or called Van Den Bosch Ngawi, the building was made lower than the land around Ngawi [1]. It surrounded by landfills is higher than that of the Castle building, for that if seen from outside the position of the castle building, it looks hidden. Folk story Ngawi, initially around there was a column filled with water and in the pond there were many crocodiles, which were maintained by the Dutch Knil Army.

The Van Den Bosch Ngawi is located in Pelem Ngawi Subdistrict, Ngawi Regency, the location is easy to reach, precisely from the Government Office of Ngawi Regency $\pm 1.5 \mathrm{KM}$ northeast, located on the ground at the corner of the Bengawan Solo River and Madiun River.

Van Den Bosch fort Ngawi, built by the Dutch Colonial in 1841 was completed in 1845, when the Dutch Army was led by Van Den Bosch. The building can accommodate \pm 250 Dutch Army Personnel, With Equipment: all Dutch Soldiers are equipped with Gun Weapons, 6 Fire Cannons and plus the strength of 60 Personnel of the Dutch Knil Army[2].

The present condition of the building of the Van Bosch castle / Benteng Pendem Ngawi, which stands on the ground $\pm 15 \mathrm{Ha}$, with the main building area $165 \mathrm{M} 2 \times 80 \mathrm{M} 2$. It is surrounded by a wall as high as $\pm 4 \mathrm{M}$. There is only one entrance from the west heading east to the Van Den Bosch Building, and guardend by several unit Personnel from the Armed Ngawi Battalion, outside the Fort Pendenm building there is already a Tourism building built by the Regional Government Ngawi Regency[3].

According to Totok Sugiharto Staff of the Tourism, Youth and Sports status the ownership of Benteng Van Den Bosch is owned by the Kostrad Dua Infantry Division. The Regional Government of Ngawi Regency has cooperated in the use of land assets and the building of the Van Den Bosch fortress area in the presence of an MOU 188/3258 / 404.107 / 2016 Number: MOU.Dir / 03 / X / 2016 related to the revitalization of Van Den Bosch fort. So far the MOU has been established between the Government of Ngawi Regency and the Kostrad Two Infantry Division but have not yet reached agreement cooperation related to revitalization and operations. Stages to revitalize fort of pendem [4].

One of the historical attractions that are of concern to the government in Ngawi, East Java, is Benteng Pendem or Benteng Van Den Bosch. On Friday, February 1, 2019, President Joko Widodo visited the fort while drinking coffee casually.

On that occasion, President Joko Widodo instructed the renovation of the Pendem Fort to preserve historical heritage and increase tourist visits. The head of the Ngawi Regency Tourism, Youth and Sports Office, Rudi Sulisdiana said the funds for the restoration of Fort Van Den Bosch were estimated at Rp 150 billion.

Until this research was written that the news 17 September 2019 on www.antaranews.com [5] reported that the van den bosch restoration plan was still awaiting the financial decisions of the relevant ministries. The improvement plan would still be discussed and still needed a lot of coordination with the Ngawi tourism office, the ministry of work public and public housing which will be disbursed in three years starting 2020 .

Overall, the promotion program implemented by the Department of Tourism and Youth and Sports of Ngawi Regency has been able to attract tourists but has not been maximized as evidenced by seeing visitor data that has increased the number of tourist visits from year to year that has not met the expected target [6].

So it is very suitable for the Readers of this Research, to visit the location of Van Den Bosch Fort Ngawi, the Legacy of the Dutch Knil Army, which is close to the Solo River, as a 
form of participating to see and preserve the nation's cultural history, while enjoying tourism around the "Van Den Bosch Fort Ngawi".

The study a challenge for the authors to examine how the promotion carried out by the Office of Culture Tourism Youth and Sports in Ngawi Regency in order to increase the number of visitors to Van Den Bosch fort has been running effectively.

\section{RESEARCH METHOD}

This study used content analysis approach, a research approach that focuses on the deep investigation about an object. The object of this study was the van den bosch fort Ngawi. The data was obtained by purposive sampling technique to focus on object with certain content related purpose of the study. The obtained data were analyzed by using interactive analysis model. This model consists of three stages, namely data collection, data reduction, data display and conclusion [7].

\section{RESULTS AND DISCUSSION}

Based on the results of the presentation and data analysis, the Department of Youth and Sports Tourism of Ngawi Regency in promoting Van Den Bosch Fort forms of promotion, namely 1) Social media consisting of Facebook and YouTube. 2) Mix promotion with events, advertising, public relations and personal selling [7].

The Ngawi Regency Youth and Sports Culture Tourism Office in promoting Ngawi tourism destinations uses both offline and online media. Promotion is only limited to making billboards and brochures or leaflets on some advertisements in the offline media or online media which are only inform when before the event is held [8]. The implementation of the promotion program has been carried out by the Ngawi Regency's Youth and Sports Tourism Office, but the results have not been maximized, due to the limited budgeting of the promotion program.

The use of a promotional mix which is a combination of various types of promotions by the Ngawi Regency Youth and Sports Tourism Office in order to promote the Van Den Bosch Fort can provide maximum results. Promotion mix that leads to sales, in the form of activities in an event or event that is integrated with advertising. The Ngawi Regency Youth and Sports Tourism Office combines various promotions in the form of advertisements, positive publicity, word of mouth promotions, sales promotions, public relations, personal selling [5]. The promotion can uses many kinds of digital media [9].

The targets and objectives of the Youth and Sports Tourism Office to promote the city of Ngawi improve services to the main community of prospective regional tourists and tourists outside the region. They will feel at home and want to return to Ngawi and even will invite their families, relatives and groups to enjoy the history, culture and the culinary. To achieve these objectives the Ngawi Regency's Youth and Sports Tourism Office implemented a marketing development and tourism partnership program. A tourism destination development program and a program to increase resources and develop the creative economy (Source: 2017, Ngawi Regency Dispora Renstra).

The evaluation phase has been carried out well, namely by evaluating the results of the promotion, the Office of Youth Tourism and Sports Ngawi Regency uses an external analysis by counting the number of visits with a sampling system [10]. The good programs have been carried out while making improvements to programs that are still experiencing weaknesses, it is very possible the Ngawi District Youth and Sports Tourism Office in introducing Van Den Bosch Fort tourism to achieve future goals and objectives. 
Ngawi regency tourism promotion planning activities have been included in the promotion planning, although most of the tourism objects are still controlled by other parties. The Benteng Pendem tourism needs a policy and a MoU. It is held for related parties because Pendem Fort is still under the auspices of the Army, namely Yon Armed 12.

Broadly speaking, the Objectives, Targets, Strategies and Policies of the Office of Youth and Sports Tourism of Ngawi Regency as conveyed by Mr. Totok the head of Tourism in an interview on 5 May 2019 as follows:

The Ngawi Regency Youth and Sports Tourism Office has the aim of increasing the economic growth of the Ngawi region. The target is to increase the economic growth supporting the tourism sector, the strategy develops old and new tourism objects by carrying out effective promotion methods, while the policy adopted by the department is to develop tourism objects both in the regional scale, nationally and internationally as well as conducting MoUs to related parties because most of the attractions in Ngawi Regency are still in the possession or control of other parties (Interview with Mr., Totok Head of Tourism Dispora, Ngawi Regency).

The problems faced by the Ngawi Regency Youth and Sports Tourism Office in fostering the Youth and Sports Culture Tourism Office in terms of OPD services that must be achieved can be identified as follows: a) Number of integrated object tourism. The most striking problem is in the integration of attractions, this is due to the ego / desire that is strong enough from each region in terms of bringing tourists. Moreover, at this time each region has not yet established an education in the development of the tourism sector. There will be a lot of competition of similar destinations. The fact should have an agreement between regions to integrate tourism objects so that dynamic cooperation will occur in the development of the tourism sector [10]. b) Number of Tourists: 1) Lack of funds and support to develop Tourism in Ngawi. 2) Ngawi Regency only has 2 (two) tourism objects that can be managed, namely the Tawun Bath Park and the Trinil Museum. 3) There are still many Tourism Objects that are not included in the management of Ngawi Regency due to the absence of an MoU with related parties. 4) Competition between regions in the tourism sector is increasingly high.

The main purpose of the promotion of the Office of Youth Culture and Tourism Ngawi regency sports in the future trying to manage tourism Benteng Pendem independently and apart from other agencies. It can be maximally managed by the Youth and Sports Tourism Office in achieving goals. People have more interest in media audio visual [11]. This has been done in an approach to related parties who are still managing Pendem Fort [10].

According to researchers, the Office of Tourism and Youth Culture Sports district of Ngawi did not introduce Van Den Bosch Fort specifically because of the Culture and Youth Tourism Office Sports does not have a specific program / agenda. The program in general, to introduce tourist destinations in the district Ngawi [12]. Also in determining the audience of the Office of Tourism Youth Culture and Sports do not consider aspects demographic, geographical and psychographic. This means manager of Van Den Bosch Fort in promoting implements promotion for all people, all ages and range as broad as possible. If the manager of Pendem Fort can support with the program of the Department of Culture and Youth Tourism Sports district 
of Ngawi, that it is possible to find ideal in determining the target audience in introducing Van Den Bosch Fort [13].

Based on the statement above according to the author, it has not an MoU between the Office of Youth Culture and Tourism Sports with the manager of the Pendem Fort management mainly determine the target audience. It is very clear to have deficiencies in mapping the target audience because the message that was made in a promotional media not necessarily acceptable to all the different layers of market segments. This is caused by each market audience has a variety of segments kinds of characteristics, needs or desires that must be understood [8].

\section{CONCLUSIONS}

From the discussion above, it is concluded that the promotion can be optimally influenced by tourism visited the object. This is reinforced in the results of Murti research which states that evaluation of promotions must be carried out in a planned and continuous manner so as to attract the interest of visitors. Based on data from visits to Van Den Bosch tourism objects, it seems that they have not met the target planned by the Ngawi Regency tourism office, so that Van Den Bosch fort has not been effectively utilized as an education cultural preservation based slow of revitalization and tourism visitors have not target of Ngawi government.

\section{REFERENCES}

[1] M. Purnawati, "Perubahan Fungsi Benteng Pendem Van Den Bosch Di Ngawi Pada Tahun 1962-2011," Avatara, vol. 6, no. 2, 2018.

[2] F. N. U. R. Hanifah, "Museum Sejarah Benteng Van den Bosch dengan Metode Hybrid Architecture." Universitas Gadjah Mada, 2016.

[3] K. Karyoto, N. Nurbaedah, and S. Sholahuddin, "Keududukan Hukum Para Pihak dalam Sengketa Tanah dan Bangunan Benteng Pendem Ngawi-Ex Knil Belanda," Diversi, vol. 4, no. 2.

[4] J. A. Widayat and S. T. Wisnu Setiawan, "Revitalisasi Kawasan Bentang Van Den Bosch Ngawi Dengan Pendekatan Adaptive Reuse Dan Konsep Infill Design." Universitas Muhammadyah Surakarta, 2018.

[5] D. P. Nugraha, "Strategi promosi dinas pariwisata kebudayaan pemuda dan olah raga kabupaten ngawi dalam meningkatkan jumlah pengunjung tempat wisata benteng pendem tahun 2016-2017," 2018.

[6] I. Gunawan, "Metode penelitian kualitatif," Jakarta Bumi Aksara, 2013.

[7] P. W. Prastiti, "Promosi benteng pendem (van den bosch) oleh dinas pariwisata kabupaten ngawi dalam upaya memperkenalkan produk wisata baru kepada masyarakat." upn" veteran" yogyakarta, 2016.

[8] I. R. Puspitawati and A. Susanto, "potensi usaha pariwisata alam di kawasan wanawisata waduk pondok kabupaten ngawi," j. agri-tek, vol. 16, no. 2, 2016.

[9] W. H. Setyawan, A. Budiman, D. S. Wihara, T. Setyarini, R. Rahim, and M. B. N. Wajdi, "The effect of an android-based application on T-Mobile learning model to improve students' listening competence," in Journal of Physics: Conference Series, 2019, vol. 1175, no. 1, p. 12217.

[10] A. S. Lestari, "Evaluasi daya tarik untuk pengembangan objek wisata alam di Kabupaten Ngawi." Universitas Negeri Malang, 2015.

[11] W. Setyawan, "T-Mobile Learning Android Model-Based to Improve Students' 
Listening Capability," in Proceedings of the 1st International Conference on Education Innovation (ICEI 2017), 2017, pp. 360-364.

[12] E. K. Candra, "The use of van den bosch fort cultural heritage as a history learning resource for senior high school students in ngawi," in proceeding: international conference, p. 208.

[13] K. Saddhono and S. Supeni, "The role of dutch colonialism in the political life of Mataram dynasty: A case study of the manuscript of Babad Tanah Jawi," Asian Soc. Sci., vol. 10, no. 15, 2014. 